\title{
Who authors crafts? Producing woodcarvings and authorship in Oaxaca, Mexico
}

Book or Report Section

Accepted Version

Cant, A. (2016) Who authors crafts? Producing woodcarvings and authorship in Oaxaca, Mexico. In: Wilkinson-Weber, C. M. and Ory DeNicola, A. (eds.) Critical Craft: Technology, Globalization, and Capitalism. Bloomsbury, London, pp. 19-34. ISBN 9781472594860 Available at http://centaur.reading.ac.uk/86153/

It is advisable to refer to the publisher's version if you intend to cite from the work. See Guidance on citing.

Publisher: Bloomsbury

All outputs in CentAUR are protected by Intellectual Property Rights law, including copyright law. Copyright and IPR is retained by the creators or other copyright holders. Terms and conditions for use of this material are defined in 
the End User Agreement.

www.reading.ac.uk/centaur

\section{CentAUR}

Central Archive at the University of Reading

Reading's research outputs online 
Cant, Alanna 2016. 'Who Authors Crafts? Producing woodcarvings and authorship in Oaxaca, Mexico.' In Critical Craft: Technology, Globalization, and Capitalism, edited by Clare Wilkinson-Weber and Alicia Ory de Nicola. London: Bloomsbury, pp. 19-34.

'The best spot painting you can have by me is one painted by Rachel.'

- Damien Hirst

One hot summer afternoon in 2008, a group of tourists from the United States arrived at the household-workshop of Miguel and Catalina García, located at the end of a dusty road on the edge of the small village of San Martín Tilcajete in the southern Mexican state of Oaxaca. ${ }^{12}$ Their tour guide had brought them there in order to see a demonstration of the intricate carving and painting techniques that have made the Garcías successful artisans within the competitive world of Mexican crafts and folk-art. Throughout the demonstration, Miguel introduced by name many of the artisans who work in his workshop, carving, painting and sanding the soft copal wood into their fine finished forms. After the demonstration was over, I spoke for some time with a number of the women in the group, while the others perused the small shop where carvings were for sale. As we stood under the shady awning in the courtyard of Miguel and Catalina's home, one of the women mentioned that she had appreciated visiting their workshop because, as she put it, she was 'more interested in ethnic art than crafts.' I asked her what was it about their work that made it art, and she described how it showed 'real creativity and passion' and that 'there was something unique in each piece [and]... you could see how Miguel and Catalina put themselves into the work.'

A few weeks later, a different group of American tourists visited the Garcías' workshop. As Miguel's explanation of the painting finished, and the group moved towards the carving area, I noticed one young woman had hung back and was looking closely at the piece Citlali, a painter in her early twenties, was just finishing. Although the woman seemed 
interested in the piece, she was asking Citlali in Spanish how long she had worked there for. Citlali answered 'two years,' and looked up, smiling. Dropping her voice, she then asked, 'and do you ever get to sign your own work, or is it always signed by the jefes (bosses)?' Citlali's smile flickered for a moment, and then she answered, 'We are all people of this workshop, and this is the name of the workshop, so that is our signature.'

While we may speculate on the dispositions or motivations of these two women whose interpretations of the Garcías' workshop were in such disagreement, it was my own reactions to these events that allowed me to glimpse the central problem they posed. From my 'in the field' perspective, I was surprised by both: I had been shocked that the first woman was able to feel that Miguel and Catalina had 'put themselves into the work' when she had just met a number of the Garcías' employees who spend their days painting and carving in their workshop. At the same time, I was also surprised that the second woman did not understand that the signature applied to the bottom of the Garcías' carvings represented something more than just the labor put into the piece; that it stood in for the creative work of the Garcías themselves, which was expressed through the workshop's general style. That these observations did not seem inherently contradictory from a perspective situated within workshops in Oaxaca points to the conceptual conflicts inherent in the production of craftwork by named individuals, a conflict that is both about definitions of 'art' and 'craft' and, at the same time, about authorship itself.

In The Craftsman, Richard Sennett claims that one of the ways art and craft can be sociologically distinguished is by the relative roles that agency and originality are considered to play in their production, citing Cellini's salt cellars as an example of craft-like objects that were ideologically made into works of art (2008: 68-73). That this transformation could take place, Sennett suggests, was due to the emergence of a new kind of authority founded on the 
Renaissance ideals of originality and creativity, which imbued art objects with public value because they 'exposed and expressed the inner character of [their] maker,' a belief that continues to inform popular common sense understandings of art production today (Sennett 2008: 69; cf. Soussloff 1997: 19, 34; Errington 1998: 140-141). In contrast, the public value of craft objects has come to be based on the idea of socially- or communally-produced productive skills and abilities, often thought to reflect localized place-based traditions or cultural identity, rather than being the result of the internal creative processes of individuals (Metcalf 1997: 70-71; Hickey 1997: 91-93). Thus, one of the ways that craft has been historically distinguished from art is through definitions of authorship.

The objective attribution of pure creative genius to artists has, of course, been challenged by art historians, sociologists and anthropologists, who have observed that while artists have been discursively and culturally constructed as individualized originators of aesthetic forms, in reality they produce art objects within communities of knowledge where ideas, symbols and aesthetic positions constantly circulate. Charting the nature of the relationships within these 'art worlds' has subsequently come to be a standard method within sociological and anthropological studies of art and art production (e.g. Becker 1982; Bourdieu 1993; Myers 2005). A similar deconstruction of the myth that crafts are traditional objects produced by relatively unalienated labor has also resulted in new theoretical developments concerning the relationship between artisanship and class, skill transmission, and relations of production (e.g. Ory DeNicola 2005; Wood 2008; Venkatesan 2010; Marchand 2010). Despite these developments, the specific question of how authorship is produced in the production and circulation of craftwork has not yet received the same amount of critical attention. While anthropologists working on art and intellectual property have indeed shown that the production and assignation of authorship are highly variable and inherently political processes (Myers 2002: 39-43; 323-332; 2005; Coombe 1998), the specificities of "craft" (i.e. 
those ideologies and associated physical and material processes that are commonly used to distinguish crafts from other objects), are likely to impact on these processes in unique and important ways.

In this chapter, I examine the production of the authorship of Oaxacan woodcarvings which are made in small rural villages for the tourist and ethnic art markets of Mexico and the United States. Oaxacan woodcarvings provide a particularly useful case in which to explore the emergence and production of authorship within craft contexts because - as the vignette at the beginning of the chapter illustrates - they are often ambiguously positioned between the categories of 'art' and 'craft,' and their classification frequently depends on the ways that authorship is or is not recognized within a given context. While the woodcarvings are not strictly 'traditional' Oaxacan crafts, a point I return to below, they are generally understood by producers, consumers, state representatives and others as quintessential artesanías. $^{3}$ In Mexico, artesanías, the aesthetic and material culture of the popular and rural classes, have been central to the ideological and historical consolidation of the Mexican nation since the early twentieth century (Novelo 1976; López 2010). As such, unlike the products of the travelling artisans described by Villalobos Rojas (this volume), the ideological weight that 'Mexican artesanías' carries as a category roots them to specific places of production, so that craft objects are frequently understood as being 'from places' rather than 'by people'; the geography of Mexican artesanías is therefore simultaneously the geography of the Mexican nation (Cant 2012: 49-59). Additionally, craft production and promotion remains a key mode of economic development and planning by the Mexican and Oaxacan states, especially in under-developed rural areas (Lopez 2010: 151-174). Government agencies, such as the National Fund for the Development of Artesanías (FONART) and the Oaxacan Institute of Artesanías, invest considerable time and resources into the promotion of craft products as a central component of Oaxaca's tourism and development programs. Given this historical and 
economic configuration, it is clear that the question 'who authors crafts?' is of great importance within the everyday experiences of craft producers and consumers in the Mexican case. I suggest, however, that this question is also fundamental to the anthropology of art and craft, and the discipline more generally, as authorship - in its many configurations - is at the heart of current processes of privatization, neo-liberalization and the consolidation of formal property regimes at national and global levels (Coombe 1998; May and Sell 2006; Thomas 2013). Exploring processes of authorship in contexts of craft production, where it has not conventionally been considered an essential feature, will provide valuable insights into the development and variable nature of authorship and cultural property more generally, thus throwing light onto key contemporary issues in anthropology.

While the variability of authorship in terms of definitions and usage has made it adaptable to a wide range of social contexts and conditions (Coombe 1998), this variability has also made its anthropological definition problematic. Applying Annette Weiner's ‘inalienable possessions' concept to art, James Leach (2003) and Fred Myers (2004) have argued that certain artistic objects cannot be wholly separated from their producers, as they retain an essence of their maker long after they have been exchanged. Following their lead, I start from the position that authorship can be understood as an ongoing, inalienable connection between an object and its producer, despite its being sold or given away. However, while authorship itself may be helpfully conceived as inalienable attachment, I argue that only charting inalienable connections between objects and producers is not sufficient for fully understanding the production of authorship in contexts where more than one person may be involved in their making. Instead, I suggest that along with processes of attachment, equal attention must be paid to the processes of detachment that take place between objects and people. By charting the processes by which inalienability and alienability are produced in a given context, the nature of authorship, and therefore its social and political implications, can 
be more fully appreciated. In the next section, I explore how detachment relates to the production of craftwork before addressing how these processes unfold in the woodcarving workshops of San Martín Tilcajete.

\section{Attachment and detachment in the practice of craftwork}

If authorship can be understood as the perceived ongoing attachment between an object and its producer(s), the variable recognition of authorship indicates that there is something important about the nature of production of different kinds of objects. To give a brief example, the products of the "creative industries" of the visual arts and literature are generally perceived by their publics as retaining a strong ongoing connection to those who made them, while the authors of computer software, jewelry and craftwork are often publically invisible. ${ }^{4}$ The bond of authorship - as Cellini's salt cellars show - appears to be established when something extraordinary is believed to occur during the production process; analyses of authorship therefore require the careful unpacking of ideologies and practices of production.

Recently, anthropologists working on craft have argued that presenting production as successive steps within coherent and linear processes naturalizes and generalizes the experiences of craftspeople and diminishes our ability to fully comprehend the making of objects (Wood 2008: 142; Venkatesan 2010: 168). Instead, new theories of production have been developed through two interrelated streams of research which focus on 'practice': the first explores the 'embodiment' of manual skills and techniques necessary for production through learning and apprenticeship (e.g. O’Connor 2005; Marchand 2010; Portisch 2012). The second, based firmly in phenomenological anthropology, focuses on the material practices of craftspeople and seeks to parse the observable steps of production in order to grasp what is happening in terms of experience, perception, emotions and the senses (e.g. Keller 2001; Ingold 2001; see Gowlland, this volume). 
A key theme that has emerged from this practice-oriented research is 'material engagement' or 'engaged material consciousness' (Ingold 2001:7; Sennett 2008:119-146). This idea suggests that what distinguishes the special kind of embodied knowledge of artisanal and creative production from other kinds of material knowledge is the dynamic way that the artisan feels connected to the objects and tools as she works. This connection is understood to be created through the enactment of complex systems of tacit knowledge that have been incorporated into the body through practice and repetition, rather than through the mental comprehension of explicit instructions. Artisans frequently report that it feels as if the materials themselves have an independent agency (Ingold 2001:21-25; O’Connor 2005). While the complex interactions between artisans and their tools and materials have been helpfully brought into view through the attention paid to material engagement, Thomas Yarrow and Siân Jones suggest that the over-emphasis on engagement per se has had a tendency to perpetuate popular notions of craftwork as an antidote to the alienation that is supposed to inhere in modernity and capitalist modes of production (2014). When framed in this way, an ideological continuity appears between the basic premises of 'material engagement' and the mythology of craftwork, most importantly, that they are produced through unalienated labor.

The implicit link made between craftsmanship and unalienated labor within the literature may be seen as a result of the incorporation of Marxist principles into the very definitions of 'craft,' as it was articulated in the late nineteenth and early twentieth centuries by proponents of the Arts and Crafts movement, such as William Morris and John Ruskin (Greenhalgh 1997: 32-36; Mascia-Lees, this volume). Indeed for Marx, artisans represented unalienated labor par excellence, especially in contrast to the exploitative experiences of factory workers (1976 [1867]: 460). Marx argued that factory workers' alienation was not 
only evident in their estrangement from the products of their labor, but also from the act of production itself, which he described as 'self-estrangement [through the worker's experience of] his own activity as an alien activity not belonging to him' (Marx 1970 [1844]): 111). In contrast, Marx and the Arts and Crafts thinkers assumed craftspeople avoided this selfestrangement through their control of the work process and their apparent heightened sensuous experience of the process, materials and forms. This belief subtly continues to influence craft studies today, and terms like 'material engagement' and even 'craftsmanship' are often implicitly taken to be antitheses of alienation from the act of production (e.g. Sennett 2008).

While this may be the case for some artisans some of the time, as Yarrow and Jones observe, this emphasis on the 'redemptive possibilities' of craft may distract from other processes that are also involved in artisanal work. Based on their research with stone masons at Glasgow Cathedral, they instead suggest that artisanal practice is made up of jointlyemerging conditions of both engagement and detachment, where detachment is understood not in opposition to engagement, but rather as a different kind of material participation within the overall production process. Yarrow and Jones report, for example, that stone masons work to intentionally detach themselves from the specific stones they have carved in order to subsume their own work into the greater, unified identity of the cathedral as a whole (2014: 270-71).

While Yarrow and Jones directs their analysis toward the practical and experiential processes involved in the work of Glasgow's stonemasons, I argue that their configuration of attachment-and-detachment can fruitfully be extended beyond the specific material relations involved in production in order to consider the processes by which the authorship of craft objects is constructed. By extending attachment-and-detachment in this way, light can be shed 
not only on the inalienable bond perceived between the woodcarvings and their recognized authors, but also on the deeply alienable relations between woodcarvings and other artisans who are intimately involved in their production. I suggest that these processes of attachmentand-detachment play out in different ways depending on the structure of the workshop in which they take place. I also argue, therefore, that questions of authorship necessarily must take into account local configurations of power, an argument that intersects with Marx's theoretical concerns about the nature of alienation in production, but advances towards a consideration of aesthetics and style. In the following sections, I describe the contours of authorship in Oaxacan woodcarving and how attachment-and-detachment materializes in San Martín's workshops.

\section{Authorship and 'having a name' in Oaxacan woodcarving}

At first glance, Oaxacan woodcarvings appear to be prototypical crafts; autochthonous aesthetic expressions grounded in the traditional peasant lifeways of rural Oaxaca. As they are produced in small picturesque villages in household-workshops where both men and women contribute to their production, the woodcarvings appear to reaffirm popular notions that craftwork is less alienated, and more personal than mass produced, industrialized goods (Hickey 1997: 84-86; Greenhalgh 1997: 105-112). Despite their current status as authentic Oaxacan cultural products, the woodcarvings produced today are not traditional in the usual sense of the word; they have a comparatively short history and the aesthetic styles in which they are executed cannot be straightforwardly described as uniquely Oaxacan. In the 1950s, sometime-mason and peasant farmer Manuel Jimenez from the village of Arrazola began selling carved masks and small sculptures to market stall vendors in Oaxaca City's market. By the 1960s, with the help of investment and guidance from craft wholesalers, he developed a particular style, taking inspiration from picture books of Mexican folktales and other traditional crafts (Chibnik 2003: 23-26; Brulotte 2012: 28-50). 
The woodcarvings began to be produced in my field site, San Martín Tilcajete, as recently as the late 1970s when FONART encouraged their production through purchasing schemes and woodcarving competitions (Chibnik 2003: 27-30; 32-34). By 2008, the production of woodcarvings contributed to the income of 68 percent of San Martín's households, although most artisans combine woodcarving production with other kinds of income-generating or subsistence activities. A sizeable minority of San Martín's workshops hire at least one employee, normally a close relative or godchild, and two large workshops hire more than five employees, corresponding to what Michael Chibnik describes as 'factorylike’ workshops (2003: 115-119). The Garcías and many others in San Martín also utilize putting-out systems, where materials and designs are provided to piece workers, usually younger women with small children, who work at home (cf. Waterbury 1991; Carrier 1992: 543-544; Milgram this volume).

Other artisans also frequently purchase unpainted carvings from more remote villages, which they paint, sign, and sell alongside their own carvings (see Chibnik 2008: 50-51; 8386). This practice was something that artisans avoided talking about in any great detail, as it was acknowledged that it did not conform to the image artisans and others provide to tourists and collectors about the woodcarvings' origins. Some expressed scorn towards those they believed to be painting the carvings of others; one well established carver I knew frequently referred to them as 'decoradores' (decorators), rather than artisans. Others, however, expressed sympathy, as they observed that some of these 'decorators' were women whose husbands had migrated to the United States, and so were economically more precarious than other households. 
Authorship is a central feature of the woodcarvings' authenticity for many customers who view them as material representations of (an essentialized) Oaxacan or Zapotec culture (but also see Cant (2012: 125-142) on other formulations of woodcarvings' desirability). That their authenticity for tourists and collectors is closely tied to their production by rural Oaxacans was rather forcefully demonstrated to me one day as I was helping an artisan paint her carvings during the busy lead-up to Christmas. When a collector discovered with shock that I, a Canadian güera, was painting carvings, she loudly insisted in front of other customers that she not be sold any pieces that I had painted. ${ }^{5}$ Although perhaps extreme, her reaction demonstrates both the perceived inalienability of authorship and the fact that in this context only certain kinds of authors are appropriate: my work threatened to create an attachment between the carving and myself rather than a 'true' Oaxacan artisan, and this bond undermined its status as an authentic cultural object, since, as described above, the authenticity of artesanias depends on the connection to the place of Oaxaca via their production by autochthonous authors. As I was clearly not an autochthonous author, my involvement in the woodcarvings' production appeared to damage their connection to Oaxaca, and hence, their authenticity itself (cf. Cant, forthcoming; Terrio 1999: 128-129; Wood 2008: 105-114; but contrast with Villalobos Rojas, this volume).

Production within family workshops is also an important feature for the carvings' appearance of authenticity. While the Western fine art tradition idealizes the individual genius as the agent of artistic creation, vernacular understandings of Mexican artesanias tie them to assumed features of peasant lifeways, in which 'the family' is taken as the most significant social unit alongside 'the village.' Household-workshops are therefore an importance space where public value is created. For many tourists I interviewed, seeing woodcarvings being made in the household-workshop environment made them more desirable than only seeing finished pieces in shops and galleries. This is because of a presumed relationship present in 
popular discourses about the nature of work within the household; household-workshops are read as spaces of unalienated and collective family labor in which 'honest work,' removed from the commercialization of the market, takes place (Dilley 2004: 803-805; Wherry 2006; Wood 2008: 46).

While 'authentic' woodcarvings appear to consumers to straightforwardly index their production in San Martín's workshops, artisans know that not everyone produces equally desirable carvings. Despite the fact that everyone in San Martín in theory should be able to produce equally authentic pieces, their highly variable successes raise concerns about what tourists and collectors are really looking for when they purchase crafts, a question that crystallizes into conflicts about competition and the copying of styles amongst artisans (Cant forthcoming). These debates are conditioned by the local view of authorship, which is constituted through the idioms of nombres (names) and estilos (styles).

In the art world of Oaxacan woodcarvings, which includes state actors, wholesalers, collectors and journalists, a specific understanding of authorship is promoted that is firstly articulated through the concept of 'names': 'A tener su nombre' (to have a name for one's self) is an important factor for success; buyers often seek out already-known artisans whose work has been documented in collectors' guides, magazines and books, and artisans require certifications from state-run organizations and competitions in order to secure invitations and visas to show their work outside of Oaxaca. The power of nombres must not be underestimated: as in other art markets, many collectors are especially concerned to have pieces by already-established artisans, while their unknown neighbors may not even warrant a visit. In February 2009, I travelled to a craft show in Tucson, Arizona, with Miguel García and two other artisans from San Martín. The show opened at ten o'clock on a Friday morning, and at ten minutes to ten, I was very surprised to see a large queue of desperate looking 
people, mostly in their sixties and seventies, waiting outside the glass doors. As soon as the doors opened, these collectors rushed to Miguel's stall, and within twenty minutes they had bought more than ten of his expensive pieces. While the aesthetics and quality of the Garcías' work is of course also important to their desirability, it was their nombre that generated the excitement at the show. When I spoke with a woman who had acquired one of Miguel's pieces, she said she felt relieved that she had managed to purchase one before they all were sold, as her sister had bought a piece from him last year, and ever since her own collection of 'Indian art' had felt incomplete. While the connection between value and renown might be apparent from the collectors' point of view, for artisans, the ability to develop a nombre is not a clear process, and often appears to be out of their own control. Because of this uncertainty, the content and rights to styles were frequently a source of discussion and concern amongst artisans.

\section{Attachment, detachment and the register of style in San Martin Tilcajete}

Given the plasticity of wood and the wide variety of ways in which carvings potentially may be painted, there is a surprisingly strong consistency in the types of carvings that are produced in San Martín. The pieces made there almost always conform to the general aesthetic characteristics established in the early years of Oaxacan woodcarving: they represent animals or traditional Mexican folk characters and are painted in the bold, bright hues that are common in other Mexican art and craftwork. While this consistency is maintained, to no small degree, by the expectations of consumers, guides, and state actors, individual artisans are also understood to have personal styles in which they execute their work. These distinctions are explained through the local idiom of estilo, or 'style,' which expresses that while an artisan's products should be consistent with the overall genre of Oaxacan woodcarvings; they ideally also carry something distinguishable from the work of others. 
Although they are never explicitly articulated as such, estilos are locally understood as the property of named individuals, rather than being traits of carvings alone, and it is estilo that allows the authorship of some carvings to be instantly recognizable to artisans as well as collectors. ${ }^{6}$ However, as with nombres, not all artisans manage to develop a recognizable estilo, and those that have, are understood to have achieved some level of success that accords them respect, and may guarantee them financial security. Although the popular and academic literatures about Oaxacan woodcarvings, as well as artisans themselves, discursively frame estilos as belonging to named individuals, I argue that styles actually adhere to workshops as spatio-social entities that themselves are owned. In most cases, those who work in the same workshop produce the same style of carving and painting.

There are, of course, a few exceptions to this rule: one artisan in his late fifties and his adult son work together in their household compound, where both live with their families. Their work, however, is quite distinct, and the son sells his work under his own name. However, a significant number of pieces in San Martín are at least partially made by people who are not considered the authors of the carvings they produce. Pieces by Tomás Castillo, for example, which are sold in his workshop in San Martín, in galleries and online, are not only made by him. Although Tomás has developed his own carving style, and carves the pieces himself, his wife Lupe has a hand in their production. She paints almost all of the pieces her husband carves, and has worked to develop her own painting style, which has become characteristic of their work together. Yet, the pieces are always signed 'Tomás Castillo' and they are considered to be quite collectible, as Tomás has made his name over the years and he is also the son of one of the original carvers in San Martín. In cases where workshops carry the name of the family (e.g. 'workshop of the Salazar Pérez family'), the surnames used are always that of the adult man, not his wife or older children of the household who participate in production. ${ }^{7}$ 
The division of tasks within production processes serves to reinforce the detachment of women and children from authorial connections to their work. Carving and painting are frequently undertaken by different members of the workshop, as carving is generally only done by men and older boys. ${ }^{8}$ Although it is sometimes reported in the popular press that the woodcarvings are produced through a clear gendered division of labor where women do most of the painting, many of the male carvers I knew also painted their own work. However, in almost all of these cases, the carvings the men painted carried their own signatures, and only in one case was a woman painter's authorship recognized in lieu of her brothers who carved. Despite the fact that it is in the painting where style is most visibly recognizable, authorship attaches in most cases to the author of the form. The elevation of creation over decoration is therefore a significant factor within these processes, and is underscored by the fact that artisans often call their products tallados de madera ("wood carvings") or figuras (figures), emphasizing the three-dimensional form of the objects, rather than their colors and surface designs. ${ }^{9}$ This division is also reinforced through some artisans' discourses that describe women and children's work as 'helping,' rather than work in its own right. Thus, the notion that unique styles of carvings are the creations of adult male woodcarvers works to detach authorship from the women and children who frequently participate in their production.

The register of estilo works even more dramatically to condition the processes of attachment-and-detachment at work in large workshops like the one owned by Miguel and Catalina García. As the piece formed by a carver is completed, he relinquishes aesthetic control to the painter who then takes it forward. I asked carvers in both of the larger workshops if they ever made suggestions about the way a piece should be painted, but no one said that they did; most said that they rarely thought about colors or surface designs, since after it left their hands, it became someone else's piece to work. While this does not constitute 
a complete detachment from the object, as carvers continue to acknowledge and point out which carvings they have made, they no longer consider them objects with which they can materially engage. This suggests to me that the inalienable connection that Weiner and others have observed between people and objects may be one of degrees; that different kinds of alienability and inalienability may co-exist, depending on the nature of the relations that are involved within production and circulation.

The ability to work on a piece or have decision-making power about its form or color, however, does not necessarily translate to a full recognition of authorship. As illustrated by the conversation between Citlali and the tourist at the beginning of the chapter, despite the fact that up to four different individuals might work on a single piece in the Garcías' workshop, the signature is always 'Miguel and Catalina García' ${ }^{10}$ In fact, Miguel and Catalina themselves frequently do not work at all on the pieces that bear their names. These interconnected processes of detachment and attachment are conceptually reinforced through the idiom of estilo, which is produced and reproduced - but not necessarily recognized - at the level of the workshop. Despite the fact that many talented artisans work for them, Miguel and Catalina are considered the true authors of the woodcarvings by virtue of the fact that they are regarded as the authors and owners of the estilo in which the carvings are made.

Their style of carving was initially developed by Miguel over a period of approximately three years in the early 2000s as he and Catalina worked to develop their nombre. Today, Miguel very rarely carves pieces himself, and yet the creative work of authorship is still considered to have been done by him, even when employees produce specific forms that he has never made. Similarly, Catalina is the person who is understood to have developed the painting repertoire of the workshop, including their unique color combinations and their specific patterns and designs; through their forms and decoration, the 
Garcías' carvings are easily distinguished from the work of their neighbors. However, it is not just the products of the workshop that are seen as specifically belonging to Miguel and Catalina, but the style itself. David, one of the painters, also helps his own parents paint their carvings in the evenings after he has finished work. He explained to me that he would never paint his father's carvings in the style that he worked in at Miguel and Catalina's, even though they sell for higher prices. He said that this would not be fair, because it would be like stealing, and I never saw pieces at his parents' workshop that were at all similar to Catalina's painting style. He did admit that sometimes ideas come to him during his work day, and that they are probably influenced by the Garcías' estilo, but that was as far as one should go.

While the nature of authorship in Miguel and Catalina's workshop is such that the pieces always remain firmly attached to themselves, the detachment of woodcarvings from the employed artisans who make them is not always complete. Jaime, who is the son of another well-known artisan and has worked for Miguel and Catalina for over three years, is considered one of the most talented painters in their workshop. While the pieces he paints in general match Catalina's stylistic repertoire, he often incorporate flourishes that are recognized by everyone - including the Garcías - as distinctly Jaime’s. For example, he will often insert a space within the usual geometric lines in which he might paint a scene, such as women making tortillas, or ancient Mexicans building pyramids. Other times, he produces new iconography within Catalina's standard geometric patterns, and plays with differences in scale or color to produce pieces with a distinct difference.

Because of the uniqueness of his pieces, which is paired with very high technical execution, they not only earn more money for Miguel and Catalina, but they also have won Jaime a great deal of respect throughout San Martín. Two of his own pieces (carved and painted at home in the evening) were featured in a special exhibition in the State Museum of 
Popular Art and many of the other artisans in San Martín recognize that Jaime is one of the most talented painters in the community. Although he is able to exercise some aesthetic agency and maintain some authorial attachment to the pieces he produces at Miguel and Catalina's, members of Jaime's family were at the same time concerned that his estilo was being appropriated into the general style of the Garcías' workshop; they thought that he would be better off working on his own to develop his nombre. For his part, Jaime explained to me that he preferred working at Miguel and Catalina's because he had enough freedom to try out new painting techniques and ideas, while at the same time he earned a steady income of cash - something very desirable to a young man planning on marrying in the next few years. He also said it was more fun working in the large workshop with others his own age than at home with his small family.

Although Jaime's relationship to the work he produces at Miguel and Catalina's manages to retain some kind of bond of authorship, it is in many ways the exception that proves the rule. Of the twenty five or so painters who work for the Garcías, only Jaime's work is thought to be somehow exceptional within the general repertoire. Further, this authorship, while acknowledged amongst San Martín's artisans themselves, is not publicized to the tourists and collectors who purchase Jaime's work at Miguel and Catalina's - they are never told which painter or carver has produced the pieces they purchase. Although the Garcías encourage some of their more talented employees to begin to build nombres for themselves, this work is not to be done during work hours; pieces actually produced in the Garcías' workshop must remain firmly attached to them, and it is expected that pieces produced by employees outside of work will be stylistically distinct from the Garcías' estilo.

\section{"Detachment" as analytical concept}


The ethnography presented here highlights the need to address both the processes of attachment and detachment that necessarily take place when authorship is assigned. The aesthetic understandings of Oaxacan woodcarvers and other members of their art world work to maintain the authorial and inalienable connection between named artisans and the woodcarvings that are produced in their workshops, while at the same time work to detach the carvings from others who are also intimately involved in their production. In San Martín, these issues of authorship and power are connected to certain artisans' ability to participate directly in the market for their goods. Given currently circulating notions of cultural authenticity in Oaxaca, in principle, all artisans in San Martín should be able to produce equally desirable woodcarvings. In reality, however, the conditions of the market mean that some named artisans are more successful than others, and that many artisans are not recognized by names at all. These complex processes of attachment-and-detachment are made most visible in moments of uncertain authorship, such as when artisans paint and sign carvings made by others in remote villages. However, these processes are equally present in the more commonplace practices within workshops, which are promoted by the art world itself, where the ownership of styles subsumes the authorship of women, children and employed laborers.

Although theoretical approaches to art and craft within anthropology have focused for very good reasons on the socially-creative and productive aspects of material production, my data suggests that we must also pay equal attention to the associated processes of social deconstruction - what I have called here 'detachment.' By only charting the inalienable connections that Weiner and others have observed between objects and producers, we miss a rich opportunity for insight into the nature of the status of 'author,' a social condition that lies at the heart of many significant legal, political and social conflicts today. My data suggests the possibility that inalienable connections may be of degrees and that different kinds of 
alienability and inalienability may co-exist, indicating rich opportunities for future research by craft scholars.

The concept of 'detachment' may also prove to be a useful tool for craft analysis beyond questions of authorship. Many of the other chapters in this volume provide vivid ethnographic accounts of processes that can be usefully read through an attachment-anddetachment lens. Mira Mohsini's analysis of the political-economic structures that divide 'labor' from 'skill' in the work of Old Delhi's weavers shows how the status of artisan has become attached to particular, officially recognized, classes of people, while it has been detached from the actual artisanal practices of weaving and embroidery. As Mohsini shows, however, while the artisan category now is intimately connected to a recognized group, individuals themselves may be detached from that group, losing their artisan status, and returning to the pool of 'labor.' Geoffrey Gowlland's chapter likewise shows how these processes are constituted through divisions of labor between potters and glazers in rural Taiwan. Like Yarrow and Jones, Gowlland observes that the practices of artisans constitute material attachments and detachments between objects and producers. At the same time, he suggests that discourses of skill and value work to elevate those who work with glaze, while simultaneously demote those who work with clay. These discourses also intersect with complex understandings of the nation, as the history of Taiwanese ceramics is inexorably linked to China, creating an historical (and highly political) dissonance with Taiwanese nationalism.

The chapters by Fran Mascia-Lees and Millaray Villalobos Rojas provide thoughtprovoking examples of how detachment may not always be imposed onto unwilling subjects, but may also provide actors with opportunities and means through which to create meaningful experience. Mascia-Lees' chapter in particular shows the complicated intertwining of 
attachment and detachment. Arts and Crafts enthusiasts in the United States constitute their 'aesthetically embodied' experiences through connections between minds, bodies, individuals and community, while at the same time use these experiences of attachment to detach themselves from what they consider to be undesirable aspects of modern capitalist lifestyles. One might ask whether detachment itself may be therefore considered one of the dimensions of 'aesthetic embodiment' explored by Mascia-Lees and desired by her research participants.

Detachment may also be seen at the heart of Villalobos Rojas' chapter about Latin American travelling artisans. Like the Arts and Crafts enthusiasts, these artisans see craft as a way to detach themselves from undesirable aspects of modern life, to 'escape the system,' as they say. At the same time, their practices also detach their products from some of the ideologies of craft I described above; their intentional impermanence in places challenges the often-held notions that crafts are grounded in places and cultures, and that artisans necessarily form coherent social classes. The material practices of travelling artisans, such as the ways they use found materials or recycle the work of others, challenges current configurations of the relationship between artisans and materials, and these material practices also may detach these objects from their original intended uses. Finally, Villalobos Rojas shows how travelling artisans' intentional detachments in turn constitute other productive connections to one another and to the ideals of the lifestyle they have chosen.

Although these studies show that detachment need not necessarily be experienced as alienation, my own work with Oaxacan woodcarvers indicates that it may be a means through which certain kinds of disempowerment may be established. While previous studies have considered how alienation and exploitation may be created through relations of power between small scale producers and other actors within the global economy (e.g. Carrier 1992), my analysis suggests that versions of these processes may also take place between producers, 
in this case within the aesthetic micro-processes involved in the production and promotion of craftwork. This suggests that it is crucial for anthropologists of craft to pay attention not only to the moments in production and marketing practices where power is overtly enacted, such as in piecework and wholesaling activities, but also within more subtle contexts of material and aesthetic practice, so that we can more fully address the nature of power that is produced through the relationships between material objects and people. 


\section{Notes}

1. Damien Hirst quoted in Burn and Hirst (2001: 82).

2. The fieldwork for this research took place over twenty months in 2008 and 2009, and was funded by the Emslie Horniman Fund of the Royal Anthropological Institute of Great Britain and Northern Ireland. All personal names in this chapter are pseudonyms, with the exception of Manuel Jimenez.

3. Artesania: the Spanish term for 'craftwork,' which I argue elsewhere is not entirely coterminous with English usages of 'craft' (Cant 2012: 49-58)

4. I do not mean to suggest here that the producers of computer software or other such products are not legally recognized as authors, but rather that the public does not generally consider this authorship to be an intrinsic and inherently desirable feature of the objects themselves.

5. Güera: a light, or white skinned woman; often used for white North Americans, but also for light-skinned Mexicans.

6. In contrast, when artisans refer to shared patterns and techniques, they often use the term manera (manner) (i.e. 'these carvings are made in the traditional manera').

7. Naming practices in San Martín follow the typical Mexican form where children take their apellido paterno (father's first surname) followed by their apellido materno (mother's first surname) to form their own doubled surnames. Because of this, children do not have identical surnames to their fathers, thus even in the 'family mode,' workshops' names continue to reflect the adult man's identity.

8. There are a few women carvers in San Martín, and it is noteworthy that these women are either unmarried or married to men permanently working in the United States.

9. During the 1990s gallery owners and the state appropriated the term 'alebrije' from the famous papier-mâché figures of Mexico City, in order to market the woodcarvings more widely. Oaxacan woodcarvings are now considered by many Mexicans to be part of the same genre as papier-mâché figures, although most artisans themselves insist on a distinction between the two forms (cf. Brulotte 2012:175, n.2).

10. Although Catalina's first name is included in their signature, García is Miguel's paternal surname. In her non-work life, Catalina never uses the surname García. 


\section{References Cited:}

Becker, H.S. (1982), Art Worlds, Berkeley: University of California Press.

Bourdieu, P. (1993), The Field of Cultural Production: Essays on Art and Literature, New York: Columbia University Press.

Burn, G. and Hirst, D. (2001), One the Way to Work, London: Faber and Faber.

Brulotte, R. (2012), Between Art and Artifact: Archaeological replicas and cultural production in Oaxaca, Mexico, Austin: University of Texas Press

Cant, A. (Forthcoming), 'The Allure of Art and Intellectual Property: Artisans and industrial replicas in Mexican cultural economies', Journal of the Royal Anthropological Institute.

Cant, A. (2012), Practising Aesthetics: Artisanal Production and Politics in a Woodcarving Village in Oaxaca, Mexico. Ph.D. dissertation, Department of Anthropology, London School of Economics and Political Science.

Carrier, J. (1992), 'Emerging Alienation in Production: A Maussian History', Man (n.s.) 27(3): 539-558.

Chibnik, M. (2003), Crafting Tradition: The Making and Marketing of Oaxacan Woodcarvings, Austin: University of Texas Press.

Coombe, R. (1998), The Cultural Life of Intellectual Properties: Authorship, Appropriation, and the Law, Durham: Duke University Press.

Dilley, R. (2004), 'The Visibility and Invisibility of Production among Senegalese Craftsmen', Journal of the Royal Anthropological Institute 10(4): 797-813.

Errington, S. (1998), The Death of Authentic Primitive Art and Other Tales of Progress, Berkeley: University of California Press.

Greenhalgh, P. (1997), 'The Progress of Captain Ludd', in P. Dormer (ed), The Culture of Craft, pp. 104-115, Manchester: University of Manchester Press.

Hickey, G. (1997), 'Craft Within a Consuming Society', in P. Dormer (ed), The Culture of Craft, pp. 83-100, Manchester: University of Manchester Press.

Ingold, T. (2001), 'Beyond Art and Technology: The anthropology of skill,' in M.B. Schiffer (ed), Anthropological Perspectives on Technology, pp. 17-31, Albuquerque: University of New Mexico Press.

Leach, J. (2002), 'Owning Creativity: cultural property and the efficacy of custom on the Rai Coast of Papua New Guinea', Journal of Material Culture 8(2): 123-143.

López, R.A. (2010), Crafting Mexico: Intellectuals, Artisans and the State after the Revolution, Durham, NC: Duke University Press. 
Keller, C.M. (2001), 'Thought and Production: Insights of the Practitioner', in M.B. Schiffer (ed), Anthropological Perspectives on Technology, pp. 33-45, Albuquerque: University of New Mexico Press.

Marchand, T. (2010), 'Embodied Cognition and Communication: studies with British fine woodworkers', Journal of the Royal Anthropological Institute 16 (s1): 100-120.

Marx, K. (1970 [1844]) 'Economic and Philosophic Manuscripts of 1844' in D.J. (ed) M. Milligan (trans), London: Lawrence and Wishart Ltd.

Marx, K. (1976 [1867]) Capital: A Critique of Political Economy, Ben Fowkes (trans), London: Penguin Books

May, C. and Sell, S.K. (2006), Intellectual Property Rights: A Critical History, Boulder: Lynne Rienner.

Metcalf, B. (1997), 'Craft and Art, Culture and Biology, in P. Dormer (ed), The Culture of Craft, pp. 67-82, Manchester: University of Manchester Press.

Myers, F. (2002), Painting Culture: the making of an Aboriginal high art. Durham: Duke University Press.

Myers, F. (2004), 'Introduction: The Empire of Things', in F. Myers (ed), The Empire of Things: Regimes of Value and Material Culture, pp. 3-61, Santa Fe: School of American Research Press.

Myers, F. (2005) 'Some Properties of Art and Culture: Ontologies of the Image and Economies of

Exchange', in D. Miller (ed), Materiality, pp: 88-117, Durham: Duke University Press.

Novelo, V. (1976) Artesanías y Capitalismo en México, Mexico City: Instituto Nacional de Antropología e Historia.

O'Connor, E. (2005), 'Embodied Knowledge: The expert of meaning and the struggle towards proficiency in glassblowing', Ethnography 6(2): 183-204.

Ory deNicola, A. (2005), 'Working Through Tradition: Experiential Learning and Formal Training as Markers of Class and Caste in North Indian Block Printing', Anthropology of Work Review 26(2): 12-16.

Portisch, A.O. (2009), 'Techniques as a Window onto Learning: Kazakh Women's Domestic Textile Production in Western Mongolia', Journal of Material Culture 14(4): 471-493.

Sennett, R. (2008), The Craftsman, London: Penguin Books.

Soussloff, C.M. (1997), The Absolute Artist: The historiography of a concept, Minneapolis: University of Minnesota Press.

Terrio, S.J. (1999), 'Performing Craft for Heritage Tourists in Southwest France', City and Society 11(1): 125-144. 
Venkatesan, S. (2010), 'Learning to Weave; Weaving to Learn... What?' Journal of the Royal Anthropological Institute 16 (s1): 158-175.

Waterbury, R. (1991), 'Embroidery for Tourists: a contemporary putting-out system in Oaxaca, Mexico', in A. Weiner and J. Schneider (eds), Cloth and the Human Experience, pp. 243-

272, Washington DC: Smithsonian Institution Press.

Wherry, F.F. (2006), 'The Social Sources of Authenticity in Global Handicraft Markets Evidence from Northern Thailand', Journal of Consumer Culture 6 (1): 5-32.

Wood, W.W. (2008), Made in Mexico: Zapotec Weavers and the Global Ethnic Art Market, Indianapolis: University of Indiana Press.

Yarrow, T. and Jones, S. (2014). 'Stone is stone': engagement and detachment in the craft of conservation masonry', Journal of the Royal Anthropological Institute 20(2): 256-275. 